\title{
Linear Activity Analysis of Production for Closed-Loop Businesses-Case Study of a Hungarian Apple Juice Factory
}

\author{
Katalin Hartung \\ Department of Management Science, Faculty of Business and Economics, University of Pécs, Pécs, Hungary \\ Email: hartungk@ktk.pte.hu
}

Received 8 April 2016; accepted 13 May 2016; published 16 May 2016

Copyright @ 2016 by author and Scientific Research Publishing Inc.

This work is licensed under the Creative Commons Attribution International License (CC BY).

http://creativecommons.org/licenses/by/4.0/

(c) (i) Open Access

\section{Abstract}

In the context of closed-loop and integrated production systems Koopmans linear activity analysis of production provides a relevant method for decision makers. The benefit of the method is to consider alternative production technologies at a time and model multiple material flows (inputs and outputs, including waste/pollutants) as well. In this paper Koopmans theory is proposed for modeling the reduction of waste in closed loop production processes. The method of linear activity analysis provides flexibility to measure the amount of waste by setting limiting constraints justifying the purpose of the model. Based on these features the method can be used in the future for modeling Blue Economy type of businesses. The case study of a Hungarian apple juice factory compares the conventional/linear and the new/closed loop production model. Result in GAMS software yields notable outcomes for the closed-loop apple juice factory showing not only the reduction of waste and by-products, but the expansion of new value-added products and jobs at a profitable level.

\section{Keywords}

Closed-Loop Model, Production Process, Linear Business, Activity Analysis, Waste

\section{Introduction}

The balance between the three major players: environment, economy and society, was strongly affected by industrialization [1]. Negative consequences such as pollution of natural waters, depletion of natural resources (oil, minerals), soil erosion, land conversion, loss of species, and climate change (carbon emission) have been escalating for such a level where consequences in some cases are irreversible. From the 1970's it ring the bell for 
many researchers and policy makers to restrain these negative changes. The ultimate change has to be driven by careful and conscious planning where interrelatedness will be explicitly recognized between social, economic and environmental issues [2]-[6].

Businesses could play a vital role in responding sustainably to these challenges. There are several attempts for planning a sustainable supply chain where the reduction of material and waste/by-product recycling plays an important role [7]. Reference [5] for example assumed a closed-loop economy based on the regeneration of regional resources keeping the balance between technical and natural environment. An extended input-output model was developed to prove that regenerative economy might be the future. Several studies on sustainability concerned the benefits of co-production. They revealed that integrated systems are more efficient using natural resources and energy [8]-[11]. Co-production allows reusing waste generated during the production process and creates new value-added products. To promote in-plant waste recovery, numerous research works was done at different industries. For example orange waste from beverage industry [12], biodegradable wastes from grain industry [13], waste heat from steel industry [14] and so on. Waste is recovered from the manufacturing process thanks to another production technology implemented, and converted into value-added products (e.g. animal feed, renewable fuel, methane, stone paper...) to reduce environmental impacts and increase economic performance of production processes [4] [15]. Blue Economy type of businesses stands for waste recovery and coproduction as well [4]. However no literature was found to model Blue Economy type of businesses. For analyzing further this type of production process Koopmans linear activity analysis has been taken into consideration. It well confirms to analyze closed or semi-closed loop productions, because it is a practical model allowing producers to choose between a finite number of distinct activities. Relying on more than one activities helps closing the loop of production and circulating materials. In comparison with Leontief input-output model, the degree of substitutability is greater in Koopmans model. It permits choosing from different production technologies, while allowing a process to produce more than one product. That assumes the existence of an objective function and limiting constrains finding the optimal solution among several feasible sets [16]-[18]. It resonates with the concept of co-production, waste recovery, and closed-loop production systems etc. Taking the advantage of Koopmans methodology the aim of this study is to define the model for closed-loop production systems and to investigate it on the case study of a Hungarian apple juice factory. Finally compare the conventional and the closed-loop production process economic, social and environmental impact based on the case study.

\section{Model Structure}

\subsection{Framework of a Closed-Loop Model}

The principles of a closed loop model find similarities with other concepts such as regenerative economy, biomimicry approach, blue economy, circular economy, cradle to cradle [19]. The study will mainly use the term closed loop to highlight the essence of the idea, and to refer to the micro perspective of production processes.

The purpose of a conventional linear production process is a very simple model usually discussed as "takemake-dispose": resources enter the production; will be transformed into a product; and wastes generated on-site will be disposed triggering a burden for the environment. In comparison to that a closed-loop production model is already designed restorative and regenerative. It shall maintain materials, components and products at their highest utility and value [20] [21]. Closed-loop is also referred as a system where nothing is wasted or discarded into the environment [19]. In a closed loop production model therefore a waste free process might involve the implementation of new production activities independent from the core competence of the factory to reduce the amount of waste on site [2] [4] [5] [20] [22] [23]. The aim is to model a waste-free production process taking new technologies into consideration which could utilize wastes of other activities.

\subsection{Koopmans Linear Activity Analysis of Production}

The methodology introduced by Koopmans provides the best tool for analyzing closed or semi-closed loop production systems, because it handles multiple activities at the same time- $\underline{x}$ denotes the activity vector containing all production technologies, and it records several outputs $-y$ denotes the output vector listing marketable products and waste as well. This will give the chance for the closed-loop production process to use waste as resource for another activity (by-product as resource will be indicated in $\mathbf{K}$ matrix) to create a new marketable product. Based on these features, the conventional apple juice factory linear programming model was written in 
GAMS software. The objective function of the factory is to maximize profit (Equation (1.1)). Koopmans assumption was to hold the product market equilibrium. It was expressed by an inequality where final demand is less than equal the difference between output and input; if there waste disposal is free [18]. However nowadays waste disposal are expected to imply certain cost for companies, hence does not allow inequality in the equation anymore (Equation (1.2)). It has to be a strong equality. The activity vector in my model already contains all possible technologies which reduce the amount of waste on site and accordingly the output vector registers marketed products and wastes as well. Further assumption is that primary inputs are less than equal the amount of primary resource available (Equation (1.3)). The last inequality defined expresses a technical constrain stating the squeezer capacity limit to be $15,000 \mathrm{~kg}$ apple per months (Equation (1.4)). This basic model was the starting point to define the conventional apple juice factory. During the sensitivity analysis three options were tested: A) normal market environment, B) fluctuation of a product price (cider), and C) a limit on a product demand (cider). Table 1 contains the result of the sensitivity analysis which will be discussed in chapter 4 .

$$
\begin{aligned}
\text { Maximize } & \Pi=\underline{p} \underline{x}-\underline{w} \underline{s} \\
\text { Subject to } & K \underline{x}=R \underline{x}+\underline{y} \\
& D \underline{x} \leq \underline{s} \\
& s_{1} \leq 15000
\end{aligned}
$$

And $x, y, p, w \geq 0$

Symbols: $\underline{x}$-activity vector, $\underline{y}$-output vector, $\underline{s}$-primary input vector, $s_{1}$-raw apple, $\underline{p}$-price vector of products, $\underline{w}$ - price vector of primary inputs, $\mathbf{K}$-output matrix, $\mathbf{R}$-input matrix, $\mathbf{D}$-primary input matrix.

The closed-loop production model requires setting up stronger constrains as seen above. Without constrains the company will produce only those products which yields the highest profit. However the factory strategic aim is to reduce waste by creating new products using the waste as resource. Koopmans linear activity analysis could solve such a problem by setting a new constrain defining the proportion of marketable products in relation to the total revenue structure. It activates other production processes which were not operating before due to the profit maximization behavior of the company (Equation (1.6)). The last constrain is for controlling the amount of waste during the closed-loop production process (Equation (1.7)). These two constrains will initiate the closedloop system.

$$
\begin{gathered}
a_{\text {marketedproduct }} \leq \frac{\text { revenue }_{\text {marketedproduct }}}{\text { totalrevenue }} \leq f_{\text {marketedproduct }} . \\
y_{\text {waste }} \leq z_{\text {waste }} .
\end{gathered}
$$

Symbols: $\underline{a}$-lower bound vector for marketed products, $f$-upper bound vector for marketed products, $\underline{y}_{\text {waste }}$ - vector of waste, $\underline{z}_{\text {waste }}$ - upper bound vector of waste generation

In the sensitivity analysis of the close-loop model four scenarios were considered: 1 ) setting the revenue constrains for marketed products, 2) setting waste to medium level, 3) setting waste to a small amount, and 4) zerowaste production. Results are seen in Table 1 and the discussion will follow in chapter 4.

\section{Case Study: A Hungarian Apple Juice Factory}

Apple farming is considered to be a traditional activity in Hungary cultivated on 28 thousand hectares of land. There is a downward tendency in apple farming due to several reasons such as aging trees, quality problems, extensive production and poor irrigation systems. The apple seasonally grows from June until September. Usually ripe apples are classified into two categories: the first class is directly sold on the market, and the second class is for juice or other purposes.

The owner of an apple orchard at the south-west part of Hungary finds a market niche investing in a factory remanufacturing second class apples for higher margins. Conventionally juice or alcoholic beverage, called Palinka, was produced out of second class apples, but not without waste generation. By applying the Blue Economy principles the second class apples can be utilized on a more complex way by designing a sustainable closedloop apple juice factory. This new production process was carefully planned by a small team of researchers at the University of Pécs, Faculty of Business and Economics who work for the Blue Economy Research Center. 
Table 1. Results of the sensitivity analysis for linear and closed-loop apple juice factory in GAMS software.

\begin{tabular}{|c|c|c|c|c|c|c|c|c|}
\hline \multirow{2}{*}{ Table Head } & & Conv/A & Conv/B & Conv/C & Closed-L/1 & Closed-L/2 & Closed-L/3 & Closed-L/4 \\
\hline & Unit & Normal & $\begin{array}{c}\text { Cider } \\
\text { p: } 0.16 €\end{array}$ & Cider constrain & $\begin{array}{l}\text { Revenue } \\
\text { constrain }\end{array}$ & Medium waste & Min. waste & Zero waste \\
\hline Profit & Euro & 1883 & 125 & 1794 & 1359 & 1028 & 0.69 & 0 \\
\hline Labor & pcs & 1.5 & 1 & 1.5 & 2.9 & 2.4 & 0.1 & 0 \\
\hline \multicolumn{9}{|c|}{ Marketed products } \\
\hline Juice05 & botl. & 6402 & 6402 & 6402 & 6385.4 & 4877 & 3.3 & 0 \\
\hline Juice1 & botl. & 3201 & 3201 & 3201 & 3192.7 & 2438.5 & 1.7 & 0 \\
\hline Cider & botl. & 4740 & 0 & 4500 & 4789.1 & 3807.2 & 2.6 & 0 \\
\hline Liqueur & botl. & 0 & 0 & 0 & 360.6 & 329.3 & 0.2 & 0 \\
\hline Mushroom & $\mathrm{kg}$ & 0 & 0 & 0 & 59.9 & 47.6 & 0 & 0 \\
\hline Palinka & botl. & 0 & 0 & 0 & 32.9 & 30 & 0 & 0 \\
\hline Gas & $\mathrm{m} 3$ & 0 & 0 & 0 & 2.4 & 1.9 & 0 & 0 \\
\hline \multicolumn{9}{|c|}{ Waste } \\
\hline Slurry & l & 24180 & 19345.2 & 23935.2 & 20191.4 & 15000 & 10 & 0 \\
\hline Fur & l & 727.5 & 582 & 720.1 & 363.6 & 228 & 0.1 & 0 \\
\hline Compost & $\mathrm{kg}$ & 0 & 0 & 0 & 2404.8 & 2153.6 & 1.6 & 0 \\
\hline Pomace & $\mathrm{kg}$ & 0 & 0 & 0 & 2934 & 2700 & 2 & 0 \\
\hline waste apple & $\mathrm{kg}$ & 5820 & 4656.3 & 561.1 & 1653.8 & 678.4 & 0.2 & 0 \\
\hline a-cider & l & 20 & 0 & 19 & 3.8 & 1.1 & 0 & 0 \\
\hline
\end{tabular}

Data was supplied by the research team for this study. The owner of the apple orchard aim is to construct the newly designed factory in 2016. Preliminary economic calculations were required proving the feasibility and profitability of the manufacturing site.

\subsection{Conventional Production Process}

The traditional way of handling second class apples were to either sell them very cheap on the market or to produce apple juice on site and resell them for higher margin to redistributors and final consumers. Figure 1 illustrates the production process of both options, starting from the point when the raw apples enter the production site. The first production unit is washing (A) where raw apples are cleaned. As a by-product dirty water is resulted with apple particles. This enters the sewage system directly from the plant. Then the washed apple lands into the squeezing stage (B) to liquefy the apple. As a residue fur and apple waste remains which are either thrown away or best feed back to the orchards land. The third stage is for pasteurizing (C) the squeezed apple to destroy pathogens. It makes sure safe consumption of the apple juice after bottling (D). The third and fourth business units do not create any waste. Last, the product is sold on the market.

The above mentioned linear production process is profitable, however release waste into the environment. Waste has been generated in (A) and (B) production unit. If waste disposal is free, the factory has to pay for its transportation and labor still. If it is not free of charge an additional expense shall be considered. Waste treatment cost money forcing a better production process coming alive tending to zero-waste at a profitable level.

\subsection{Closed-Loop Production Process}

Monitoring energy/water/material use gives opportunity for planning an economically, socially and environmentally matured production process targeting zero-waste. Therefore the conventional production process was 


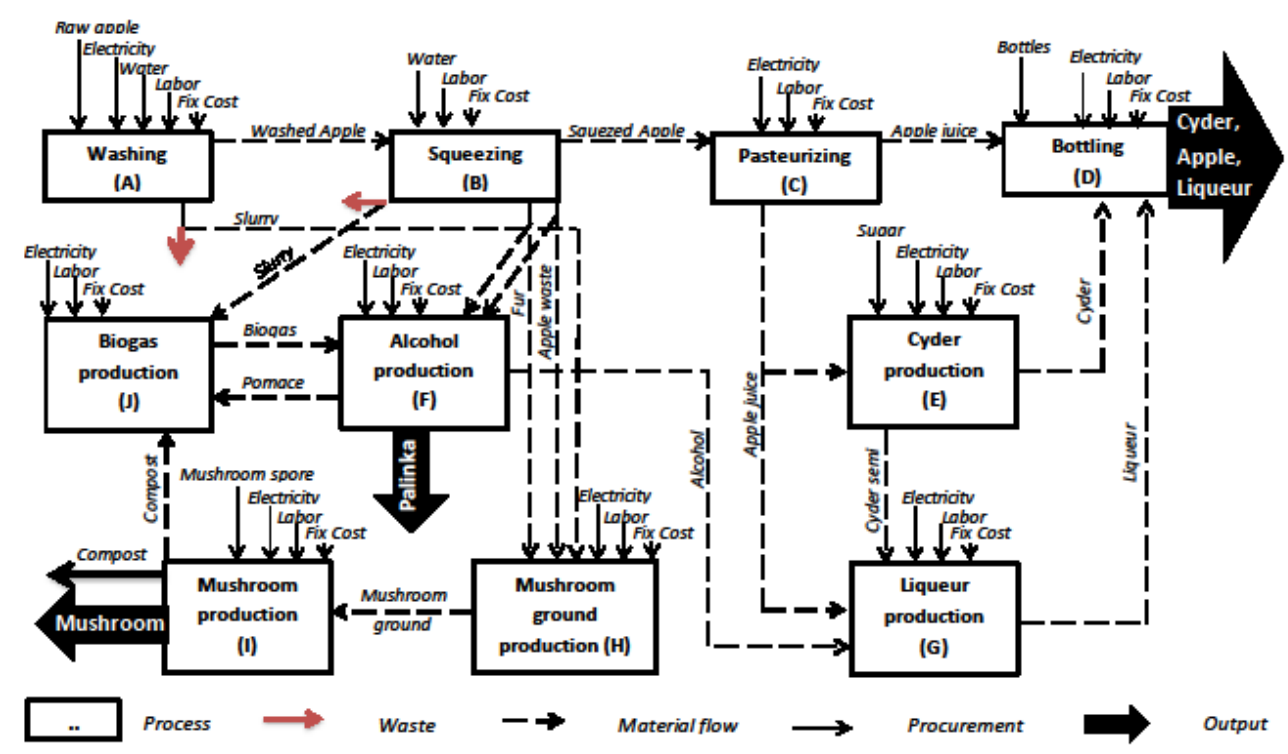

Figure 1. Linear (A-D) and closed-loop (A-J) production process of the Hungarian apple juice factory.

extended by applying the concept of closed loop business model. On Figure 1 the business units from (A)-(D) are identical with the above discussed linear process. Differences can be noticed with the closed-loop system at two points: first the product portfolio was enlarged by cider (E) and liqueur production (G); second new technologies emerged using waste as their resource creating new products: mushroom, biogas. Thereinafter slurry, fur and apple waste (generated at washing (A) and squeezing (B)) creates a mushroom ground (H) for mushroom production (I), while some part of it ends up creating alcohol by fermentation (F), called Palinka, for the market and pure alcohol for liqueur production (G). All the biological waste from (B), (F) and (I) are generating biogas (J) what fuels the alcohol producing unit (F). A system produces only slurry and forage where the latter is transported to the orchards as compost. These are indicated with the small red arrow on Figure 1.

The closed-loop production process has been able to reduce the amount of waste during operation, but still some waste is generated. Therefore the process can be called semi-closed only. It is observable that the new approach increased the number of activities from four to ten and marketable products from one to five. Koopmans linear activity analysis will find out whether the closed-loop production is able to operate well under the strategic goal of the factory to reduce waste from the production process and remain profitable.

\section{Results}

The conventional and closed-loop apple juice factory linear model was written in GAMS software. The outcome of the results was compared based on three aspects: economic, social and environmental since their balance plays major importance in our society (see chapter 1). Table 1 summarizes the results of one month production distinguishing the conventional (refer to as Conv/A-C) and closed-loop apple juice factory (refer to as Closed-L/ 1-4) production outcomes.

Economic performance can be measured through profitability. It is a universal dimension among companies to financially determine their viability. Results show that the conventional apple juice factory under normal market condition is producing both cider and apple juice in a half liter (Juice05) and in one liter (Juice1) packaging on a highly profitable level. During the sensitivity analysis it was revealed that if the market price of cider drops dramatically from $0.64 €$ to $0.16 €$ than all production will shift to apple juice and consequently the amount of profit experiences a significant 93\% fall (see Table 1 at column Conv/A,B). It turns out that cider is a leading product on the market with the highest margin. The third sensitivity analysis defines a market demand for cider to be 4500 bottles (see Table 1 at column Conv/C). That remains to be highly profitable with a slight drop of $4.7 \%$ profit compared to the first scenario.

The closed-loop apple juice production first scenario (see Table 1 at column Closed/1) seems to be the most profitable when the revenue constrains were first defined for marketed products. It was resulting $1359 €$ per 
month. If the amount of waste in the system was reduced by $25 \%$ (take slurry as reference), it consequently reduced the profitability by $25 \%$ too (see Table 1 atcolumn Closed/1-2). When the system reached the zero-waste scenario, the factory stopped producing (see Table 1 atcolumn Closed/4). It indicates that the factory is unable producing under zero-waste condition. However findings show that the environmental impact of the closed-loop production process can be diminished by 16 to 37\% by reducing the amount of waste on-site (see Table $\mathbf{1}$, refer to slurry in Closed/2,3).

Social aspect is measured by the number of workers. Results show, while the conventional apple juice factory is providing one full time and one part-time job per months, until the closed-loop production model can increase the number of workers to almost 3 full-time employees (see Table 1 at raw "Labor"). The closed-loop production model has a positive social impact above the economic one. If the amount of waste is reduced, the number of workers equally drops.

\section{Conclusion}

The study presents Koopmans linear activity analysis for a closed-loop production process. Closed-loop production means a system where by-products and wastes are reused for other production processes creating a new value-added product. During the model development Koopmans original assumption of the product market equilibrium was redefined from inequality to equality, assuming that disposal is not free of charge. Furthermore the closed-loop production was differentiated by a revenue constrain and a waste reduction constrain since the activity vector already contained all the activities necessary for closed-loop production. The case study of the Hungarian apple juice factory underlines that the conventional production is profitable however it employs less workers and produces more waste. Meanwhile the closed-loop apple juice factory generates more jobs, nearly as much profit as the conventional and less waste. The latter production model may be recommended for governmental organizations whose main objective is to enhance work opportunities and be environmentally friendly.

The method of linear activity analysis of production can be used to understand the long-term system behavior of companies with environmental conscious motivations. In the future the method provides a feasible tool to model Blue Economy type of businesses.

\section{References}

[1] Brundtland, G.H., et al. (1987) Our Common Future: Report of the 1987 World Commission on Environment and Development, Oxford, Oxford University Press.

[2] Lovins, L.H. (2008) Chapter 3 Rethinking Production. In: World Watch Institute, Ed., State of the World, Innovations for a Sustainable Economy, 25th Edition, W W Norton \& Company, Oxford.

[3] Rockström, et al. (2009) Planetary Boundaries: Exploring the Safe Operating Space for Humanity. Ecology and Society, 14, 2-32.

[4] Pauli, G. (2010) The Blue Economy: 10 Years, 100 Innovations, 100 Million Jobs. Konvergenta Publishing UG, Berlin.

[5] Szalay, Zs.E. and Dobos, I. (2011) The Closed Loop Model by Regional Economics. Proceedings of the Third Annual Conference on Globalization, Sustainability and Development, Gödöllő, Hungary.

[6] Perman, R., Ma, Y., Common, M., Maddison, D. and McGilvray, J. (2011) Natural Resource and Environmental Economics. 4th Edition, Perason, Gosport.

[7] Govindan, K., Soleimani, H. and Kannan, D. (2015) Reverse Logistics and Closed-Loop Supply Chain: A Comprehensive Review to Explore the Future. European Journal of Operational Research, 240, 603-626. http://dx.doi.org/10.1016/j.ejor.2014.07.012

[8] Kohtala, C. (2015) Addressing Sustainability in Research on Distributed Production: An Integrated Literature Review. Journal of Cleaner Production, 106, 654-668. http://dx.doi.org/10.1016/j.jclepro.2014.09.039

[9] Cavalett, O., Queiroz, J.F. and Ortega, E. (2006) Emergy Assessment of Integrated Production Systems of Grains, Pig and Fish in Small Farms in the South Brazil. Ecological Modeling, 193, 205-224. http://dx.doi.org/10.1016/j.ecolmodel.2005.07.023

[10] Bastianoni, S. and Marchettini, N. (2000) The Problem of Co-Production in Environmental Accounting by Emergy Analysis. Ecological Modeling, 129, 187-193. http://dx.doi.org/10.1016/S0304-3800(00)00232-5

[11] Wu, X., Wu, F., Tong, X., Wu, J., Sun, L. and Peng, X. (2015) Emergy and Greenhouse Gas Assessment of Sustainable, Integrated Agricultural Model (SIAM) for Plant, Animal and Biogas Production: Analysis of the Ecological Re- 
cycle of Wastes. Resources, Conservation and Recycling, 96, 40-50. http://dx.doi.org/10.1016/j.resconrec.2015.01.010

[12] Rezzadori, K., Benedetti, S. and Amante, E.R. (2012) Proposals for the Residues Recovery: Orange Waste as Raw Material for New Products. Food Bioproduction Process, 90, 606-614. http://dx.doi.org/10.1016/j.fbp.2012.06.002

[13] Klipova, I., Staniskis, J.K. and Petraskiene, V. (2013) Solid Recovered Fuel Production from Biodegradable Waste in Grain Processing Industry. Waste Management's Resource, 31, 384-392. http://dx.doi.org/10.1177/0734242X12467065

[14] Zhang, H., Wang, H., Zhu, X., Qiu, Y., Li, K., Chen, R. and Liao, Q. (2013) A Review of Waste Heat Recovery Technologies towards Molten Slag in Steel Industry. Applied Energy, 112, 956-966. http://dx.doi.org/10.1016/j.apenergy.2013.02.019

[15] Wan, Y.K., Ng, R.T.L., Ng, D.K.S. and Tan, R.R. (2015) Material Flow Cost Accounting (MFCA)-Based Approach for Prioritization of Waste Recovery. Journal of Cleaner Production, 107, 602-614. http://dx.doi.org/10.1016/j.jclepro.2015.05.024

[16] Chiang, A.C. (1984) Fundamental Methods of Mathematical Economics. 3rd Edition, McGraw-Hill, Singapore.

[17] Zalai E. (1998) Application of General Equilibrium Models to Economic Policy Analyses. (Általános egyensúlyi modellek alkalmazása gazdaságpolitikai elemzésekre). Közgazdasági Szemle, XLV, 1065-1081.

[18] Zalai E. (2012) Mathematics for Economics II. Multi-Sector Models and Macro Analysis. (Matematikai közgazdaságtan II. Többszektoros modellek és makrogazdasági elemzések). Akadémiaikiadó, Budapest.

[19] Bocken, N.M.P., Short, S.W., Rana, P. and Exans, S. (2014) A Literature and Practice Review to Develop Sustainable Business Model Archetypes. Journal of Cleaner Production, 65, 42-56. http://dx.doi.org/10.1016/j.jclepro.2013.11.039

[20] MacArthur E. (2013) Towards the Circular Economy Vol. 2: Opportunities for the Consumer Goods Sector. Ellen MacArthur Foundation, Pre-Printed Online Version.

[21] Huyman S., Debaveye, S., Schaubroeck, T., De Meester, S., Ardente, F., MAthieux, F. and Dewulf, J. (2015) The Recyclability Benefit Rate of Closed-Loop and Open-Loop Systems: A Case Study on Plastic Recycling in Flanders. Resources, Conservation and Recycling, 101, 53-60. http://dx.doi.org/10.1016/j.resconrec.2015.05.014

[22] Bistagnino, L. (2011) Systemic Design. 2nd Edition, Slow Food, Torino.

[23] Nakatani, J. (2014) Life Cycle Inventory Analysis of Recycling: Mathematical and Graphical Frameworks. Sustainability, 6, 6158-6169. http://dx.doi.org/10.3390/su6096158 